\title{
Excessive Bleeding
}

National Cancer Institute

\section{Source}

National Cancer Institute. Excessive Bleeding. NCI Thesaurus. Code C113742.

Abnormally heavy or prolonged loss of blood. 